\title{
The Optimization of Treatment and Management of Schizophrenia in Europe (OPTiMiSE) Trial: Rationale for Its Methodology and a Review of the Effectiveness of Switching Antipsychotics
}

\author{
Stefan Leucht*,1, Inge Winter-van Rossum ${ }^{2}$, Stephan Heres ${ }^{1}$, Celso Arango ${ }^{3}$, W. Wolfgang Fleischhacker ${ }^{4}$, \\ Birte Glenthøj $^{5}$, Marion Leboyer ${ }^{6}$, F. Markus Leweke ${ }^{7}$, Shôn Lewis ${ }^{8}$, Phillip McGuire ${ }^{9}$, Andreas Meyer-Lindenberg ${ }^{7}$, \\ Dan Rujescu' ${ }^{10}$, Shitij Kapur ${ }^{9}$, René S. Kahn², and Iris E. Sommer ${ }^{2}$

\begin{abstract}
${ }^{1}$ Department of Psychiatry and Psychotherapy, Technische Universität München, Klinikum rechts der Isar, München, Germany; ${ }^{2}$ Department of Psychiatry, Brain Center Rudolf Magnus, Utrecht, The Netherlands; ${ }^{3}$ Child and Adolescent Psychiatry Department, Hospital General Universitario Gregorio Marañón, IiSGM, School of Medicine, Universidad Complutense, CIBERSAM, Madrid, Spain; ${ }^{4}$ Biological Psychiatry Division, Department of Psychiatry and Psychotherapy, Medical University Innsbruck, Innsbruck, Austria; ${ }^{5}$ Center for Neuropsychiatric Research \& Center for Clinical Intervention and Neuropsychiatric Schizophrenia Research, Copenhagen University Hospital, Psychiatric Hospital Center Glostrup, Glostrup, Denmark; ${ }^{6}$ INSERM U955, Translational Psychiatry Team, Créteil, France, Paris Est University, DHU Pe-PSY, Pôle de Psychiatrie des Hôpitaux Universitaires H Mondor, Créteil, France, Fondation FondaMental; ${ }^{7}$ Central Institute of Mental Health, Medical Faculty Mannheim, Heidelberg University, Mannheim, Germany; ${ }^{8}$ University of Manchester, Manchester, UK; ${ }^{9}$ Department of Psychological Medicine, King's College London, Institute of Psychiatry, London, UK;
\end{abstract} \\ ${ }^{10}$ Department of Psychiatry, Psychotherapy and Psychosomatics Martin-Luther-University Halle-Wittenberg, Halle, Germany
}

*To whom correspondence should be addressed; Department of Psychiatry and Psychotherapy, Technische Universität München, Klinikum rechts der Isar, Ismaningerstr. 22, 81675 München, Germany. tel: 49894140 4249, fax: 498941404888 , e-mail: Stefan.Leucht@1rz.tum.de

Background: Most of the 13542 trials contained in the Cochrane Schizophrenia Group's register just tested the general efficacy of pharmacological or psychosocial interventions. Studies on the subsequent treatment steps, which are essential to guide clinicians, are largely missing. This knowledge gap leaves important questions unanswered. For example, when a first antipsychotic failed, is switching to another drug effective? And when should we use clozapine? The aim of this article is to review the efficacy of switching antipsychotics in case of nonresponse. We also present the European Commission sponsored "Optimization of Treatment and Management of Schizophrenia in Europe" (OPTiMiSE) trial which aims to provide a treatment algorithm for patients with a first episode of schizophrenia. Methods: We searched Pubmed (October 29, 2014) for randomized controlled trials (RCTs) that examined switching the drug in nonresponders to another antipsychotic. We described important methodological choices of the OPTiMiSE trial. Results: We found 10 RCTs on switching antipsychotic drugs. No trial was conclusive and none was concerned with first-episode schizophrenia. In OPTiMiSE, 500 first episode patients are treated with amisulpride for $\mathbf{4}$ weeks, followed by a 6-week double-blind RCT comparing continuation of amisulpride with switching to olanzapine and ultimately a 12-week clozapine treatment in nonremitters. A subsequent 1-year RCT validates psychosocial interventions to enhance adherence. Discussion: Current literature fails to provide basic guidance for the pharmacological treatment of schizophrenia. The OPTiMiSE trial is expected to provide a basis for clinical guidelines to treat patients with a first episode of schizophrenia.

Key words: first episode/schizophrenia/amisulpride/ olanzapine/algorithm/nonresponse

\section{Introduction}

Schizophrenia is a complex disorder frequently leading to early disability and extensive costs for national health systems. ${ }^{1}$ Major efforts are being undertaken to understand its pathophysiology and to improve outcome. To illustrate this effort, the specialized register of the Cochrane Schizophrenia Group contains 13542 controlled studies (February 2012, https://szg.cochrane.org/ cszg-specialised-register). However, the vast majority of these trials have investigated the general efficacy of pharmacological or psychosocial interventions. Very few prospective, sequential studies are available that could guide decisions which have to be made in every day clinical routine. Some of the simplest questions of clinicians remain unanswered. For example: If the first antipsychotic used has not worked, is switching to another drug effective? Or 
should we perhaps increase the dose? And when should we start clozapine, the most efficacious drug?

These questions are most urgent for patients with a first episode of schizophrenia, as the duration of untreated psychosis is an important predictor of outcome..$^{2-4}$ Optimal treatment in this early phase is of crucial importance, as swift restoration of social and professional functioning improves long-term outcome. ${ }^{5}$ First-episode patients on average respond better and faster to antipsychotic drugs. ${ }^{6,7}$ need lower doses and have a better prognosis than chronic patients. ${ }^{8}$ The first episode is therefore a critical junction in the lives of people with schizophrenia where optimal treatment could positively influence the long-term course.

The European Commission has funded the multinational, multicenter, 3-phase, randomized, double-blind "Optimization of First Episode" (OPTiMiSE, http:// www.optimisetrial.eu/) study which is one of the rare studies to test treatment algorithms. Five hundred participants with a first episode of schizophrenia will be treated for a maximum of 22 weeks according to a pharmacological algorithm including a double-blind phase on switching to a second antipsychotic vs continuation of the first, as well as an early use of clozapine in nonremitters. ${ }^{9}$ These interventions will be coupled with several other work packages to provide an extensive examination of potential biological predictors of response and a subsequent randomized controlled trial (RCT) on psychosocial interventions to improve treatment adherence. Finally, a separate RCT investigates the efficacy of cannabidiol as an alternative for antipsychotic treatment in patients with recent onset schizophrenia.

The aim of the current publication is to provide a review of the currently available sequential, randomized algorithm studies of this type, and to discuss the rationale for important methodological choices made for the medication algorithm of the OPTiMiSE trial. Companion articles will present reviews on other work packages of the OPTiMiSE project.

\section{Review of Prospective Randomized Studies on Switching the Drug in Initial Nonresponders to Antipsychotics}

\section{Method}

We searched Pubmed until October 29, 2014 for randomized trials in which patients with schizophrenia, schizophreniform, or schizoaffective disorder (any diagnostic criteria) had been treated prospectively with a first antipsychotic drug. Nonresponders (study defined) were subsequently randomized to either switching the antipsychotic or another pharmacological strategy. The search terms were: schizophreni* AND (antipsychot* OR neurolept* OR drug OR treat*) AND (switch* OR alternativ* OR consecutiv* OR subsequent OR shift OR change) AND (nonrespon* OR nonrespon* OR not*respon* OR fail*
OR resistant* OR refract* OR ineffect*), article types "clinical trials" or "randomized controlled trials." There were no restrictions in drugs and doses used, language or when the switch was performed. The results are presented in narrative form. We excluded studies in which nonresponse was established retrospectively, because we felt that establishing nonresponse in a prospective manner is a crucial component to rule out nonspecific effects of including patients in trials. We also excluded studies which had a prospective run-in phase with the only objective to establish treatment resistance before participants were randomized to 2 other antipsychotic drugs. Such studies are not concerned with the question of whether switching the drug is effective, but rather with the efficacy of a drug in treatment resistant patients..$^{10-14}$ Although the OPTiMiSE trial includes only first episode patients, we did not restrict the review to this population for which no RCTs on switching are currently available.

\section{Results}

Our search yielded 984 hits. Fourteen reports on 10 studies met the inclusion criteria and are presented more in detail in the subsequent text, for a PRISMA diagram see figure 1.

Kinon et $a^{15}$ treated 156 inpatients with acute exacerbations of schizophrenia, schizoaffective, or schizophreniform disorder for 4 weeks with fluphenazine $20 \mathrm{mg} / \mathrm{d}$. Inclusion criteria were not restricted to firstepisode patients. From these, 58 nonresponders (defined as less than "much improved" on the Clinical Global Impression Scale $\left[\mathrm{CGI}^{16}\right]$ and more than "mildly ill" on 1 of the 4 psychotic items of the Brief Psychiatric Rating Scale [BPRS $\left.{ }^{17}\right]$ ) were subsequently randomized to double-blind treatment in terms of either continuing $20 \mathrm{mg} / \mathrm{d}$ fluphenazine, switching to haloperidol $20 \mathrm{mg} / \mathrm{d}$, or to drastically increasing the fluphenazine dose to $80 \mathrm{mg} / \mathrm{d}$ (a dose that would nowadays be considered excessive ${ }^{18}$ ). After an additional 4 weeks of treatment, irrespectively of the assigned group only $9 \%$ of the patients responded. There was no significant between-group difference in any efficacy measure. From a contemporary perspective, a major limitation of the study was that fluphenazine and haloperidol are both similar high-potency first-generation drugs. Theoretically, a switch to a drug with a more different receptor-binding profile and mechanism of action might be more promising. In addition, this study was probably underpowered to detect a difference.

Klimke et al ${ }^{19}$ treated 50 newly admitted, currently antipsychotic free, but not necessarily first-episode patients with schizophrenia with haloperidol $15 \mathrm{mg} / \mathrm{d}$ intravenously for 3 days after which they were classified into early responders (markedly improved or improved on a CGI like scale) or early nonresponders, and randomized both groups to either staying on haloperidol $15 \mathrm{mg} / \mathrm{d}$ orally or to switching to perazine $300 \mathrm{mg} / \mathrm{d}$ orally 


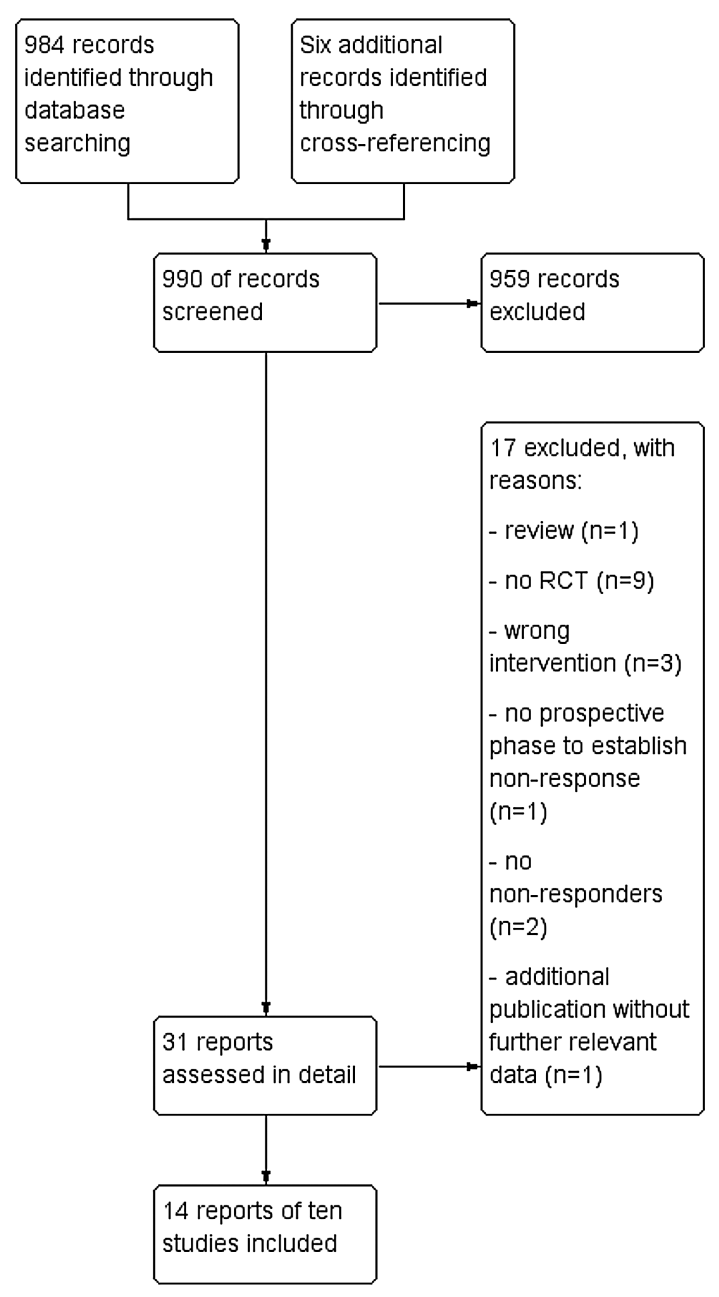

Fig. 1. PRISMA diagram of the search.

for another 3 weeks. Independently of the treatment condition, early responders improved more than early nonresponders. In contrast to the authors' initial hypothesis (that early haloperidol nonresponders would benefit from a switch to perazine), there was a trend that staying on haloperidol led to superior outcomes. The authors discussed the major limitation of their small sample size.

Shalev et $\mathrm{al}^{20}$ randomized 75 chronic or subchronic patients with acute exacerbations of schizophrenia to either haloperidol (a high-potency drug, target dose $20 \mathrm{mg} / \mathrm{d}$ ), perphenazine (mid-potency, target dose $32 \mathrm{mg} / \mathrm{d}$ ), or levomepromazine (low-potency, target dose $300 \mathrm{mg} / \mathrm{d}$ ), all given open label and flexibly dosed. Nonresponders (defined as less than 30\% BPRS total score reduction and the impossibility to discharge the patient) at 4 weeks were re-randomized to 4 weeks treatment with 1 of the other 2 antipsychotics. Patients who failed to respond in this second phase were switched to the last remaining antipsychotic. At the end of the study, $95 \%$ of the participants had responded with a tendency of stronger response to perphenazine and levomepromazine than to haloperidol. A particular strength of this study is that 3 antipsychotics from different classes and quite different properties were chosen. However, a major limitation is the lack of a control group consisting of patients who remained on the same drug during the second and third phase. It can therefore not be ruled out that the improvement was simply an effect of time.

The same criticism applies to the study by Suzuki et $\mathrm{al}^{21}$ who randomized 78 mainly chronic, but currently highly symptomatic patients to open-label treatment with either olanzapine (mean dose $18.3 \mathrm{mg} / \mathrm{d}$ ), quetiapine $(564 \mathrm{mg} / \mathrm{d})$, or risperidone $(5.47 \mathrm{mg} / \mathrm{d})$. Nonresponders (defined as less than 30\% BPRS total score reduction from baseline) after a maximum of 8 weeks were re-randomized to 1 of the remaining 2 second-generation antipsychotics and if they still did not respond they received the third drug. The overall response was relatively high (only 16 patients $(20.5 \%)$ did not respond and 7 patients $(9 \%)$ discontinued the study prematurely), and quetiapine was less efficacious than the other 2 antipsychotics in secondary outcomes. The use of 3 second-generation antipsychotics makes the study more relevant to current practice where such drugs are nowadays the primary choices in many countries.

Hatta et $\mathrm{a}^{22}$ published 2 small studies in which they treated newly admitted, acutely ill but not necessarily firstepisode patients with schizophrenia with either risperidone (study $1, n=73$, maximum dose $6 \mathrm{mg} / \mathrm{d}$ ) or olanzapine (study $2, n=58$, maximum dose $20 \mathrm{mg} / \mathrm{d}$ ) in flexible doses. The nonresponse rate at 2 weeks ( $\geq 4$ on the CGI improvement scale) was $30 \%(n=20)$ in the risperidone study and also $30 \%(n=14)$ in the olanzapine study. In both studies, those who had not improved were randomized in a rater blind fashion to either switching to the other drug or to staying on the same antipsychotic for another 2 weeks. At 4 weeks, there was no significant difference in the number of patients in remission ${ }^{9}$ nor in the number of patients with at least a 50\% reduction in PANSS total score between switching or staying. In both trials, the early improvers at 2 weeks responded better than the nonimprovers. But due to the small sample sizes the studies had only a pilot character.

In a subsequent rater-blinded study, the same researchers treated 156 patients with essentially the same inclusion criteria as in their previous trials ${ }^{22}$ with either risperidone ( $n=74$, starting dose $3 \mathrm{mg} / \mathrm{d}$ ) or olanzapine ( $n=86$, starting dose $10 \mathrm{mg} / \mathrm{d}$ ) at the clinicians' discretion. ${ }^{23}$ At 2 weeks, nonresponders (CGI-I $\geq 4, n=51$ ) were randomized to either switching to the other drug (those on risperidone to olanzapine and those on olanzapine to risperidone) or to combining the 2 drugs for another 10 weeks. In those patients started on risperidone, there was no significant difference in the number of responders ( $\geq 40 \%$ PANSS total score reduction from baseline) between the switching $(8 \%)$ and the combination group $(29 \%)$. In those patients initially started on olanzapine, there was also no significant difference in response rates between patients switching to risperidone $(25 \%)$ or combining both drugs $(50 \%)$. Small sample sizes and the lack of a "stayer" control group are again limitations of this study. ${ }^{23}$ 
The Clinical Antipsychotic Trials for Intervention Effectiveness (CATIE) study is also relevant in this context (Lieberman et $\mathrm{al}^{24}$ ) and it does not have the limitation of a small sample size. About 1460 patients with chronic schizophrenia were randomized to double-blind treatment with olanzapine $(7.5-30 \mathrm{mg} / \mathrm{d})$, quetiapine (200-800 mg/d), risperidone (1.5-6 mg/d), ziprasidone $(40-160 \mathrm{mg} / \mathrm{d})$, or perphenazine $(8-32 \mathrm{mg} / \mathrm{d})$. Patients who discontinued a second-generation antipsychotic in phase I could choose between 2 other randomization pathways in phase II. In both pathways, patients could not receive the same antipsychotic as in phase I again, so that CATIE could also not address the question whether switching a drug is better than staying on the same one. In one pathway, patients were re-randomized to clozapine (considered as the intervention), olanzapine, quetiapine, or risperidone. ${ }^{25}$ In the other one, patients were allocated to ziprasidone (intervention), olanzapine, quetiapine, or risperidone. ${ }^{26}$ It was assumed that those participants who had discontinued phase I due to inefficacy would choose the clozapine pathway while those discontinued for tolerability reasons would choose the ziprasidone pathway. Unfortunately this was not the case. Most participants who discontinued phase I $(n=444)$ chose the ziprasidone pathway, probably due to concerns about clozapine side effects. In the ziprasidone pathway, risperidone and olanzapine were more effective than quetiapine and ziprasidone. ${ }^{26}$ In the clozapine pathway $(n=99)$, clozapine was associated with the lowest discontinuation rate. ${ }^{25}$ The latter trial had the limitation that in contrast to its comparators clozapine was used open label, but it can still be used as an example for the early use of clozapine in chronic patients who had only received one previous antipsychotic during the trial. Two post hoc analyses of CATIE are also relevant here. One re-analyzed those 114 patients who had discontinued perphenazine in CATIE phase $\mathrm{I}^{27}$ These participants responded better when they received quetiapine or olanzapine rather than risperidone in CATIE phase II. A possible explanation was that the patients randomized to quetiapine or olanzapine might have benefitted from a switch to drugs with receptor binding profiles that are more different from perphenazine than that of risperidone. It therefore provides some evidence that an antipsychotic with a different receptor binding profile should be chosen if a drug is considered in cases of insufficient efficacy. Another re-analysis of CATIE phase I, however, contradicts the latter findings, because patients taking olanzapine or risperidone before entering CATIE stayed on treatment longer in phase I if assigned to stay on the same treatment. ${ }^{28}$ However, not all patients were considered treatment resistant at study entrance and this report was not replicated by similar analysis using a slightly different approach. ${ }^{29}$ Furthermore, this analysis did not have a prospective phase and does therefore not meet our inclusion criteria.
Strongest support that switching nonresponders to a different drug is effective, stems from a recent large trial in which 628 mainly chronic patients with schizophrenia or schizoaffective disorder were treated for 2 weeks with flexibly dosed risperidone $\left(2-6 \mathrm{mg} / \mathrm{d}\right.$, Kinon et $\left.\mathrm{al}^{30}\right)$. Those who had not shown at least a $20 \%$ reduction of the PANSS were randomized to double-blind treatment with either continuation of risperidone or a switch to olanzapine (10-20 mg/d) for an additional 10 weeks. The outcome of the switchers was slightly, but statistically significantly $(P=.02)$ better than that of the stayers, and the difference was more pronounced in patients who were at least moderately ill at week $2 .{ }^{30}$ In any case the early improvers at 2 weeks had a clearly better outcome than the early nonimprovers, irrespectively of the subsequently assigned treatment of the latter.

Finally, the ongoing double-blind SWITCH study ${ }^{31}$ randomizes 350 newly admitted patients with acute schizophrenia, most of whom have had multiple episodes, to treatment with either amisulpride $(200-800 \mathrm{mg} / \mathrm{d})$ or olanzapine $(10-20 \mathrm{mg} / \mathrm{d})$. Nonimprovers at 2 weeks defined as $<25 \%$ PANSS total score reduction from baseline are re-randomized to either staying on the same drug or switching to the other one for 6 more weeks. One of the strengths of this study is the double randomization. Re-randomizing amisulpride and olanzapine nonimprovers to the respective other drug or staying on the same drug rules out the alternative explanation that better improvement in the switching group is due to superior efficacy of the second drug rather than the switch itself.

In summary, only a few prospective studies on switching the antipsychotic in case of nonresponse to an initial drug are available and the only supportive randomized evidence with an appropriate design, namely a "stayer" control group, is currently available for switching risperidone nonresponders to olanzapine (Kinon et $\mathrm{al}^{30}$ ). And none of the available studies, including the SWITCH study, ${ }^{31}$ was restricted to first episode patients, making such trials a research priority (see Table 1).

\section{OPTiMiSE Trial Design}

The OPTiMiSE trial (http://www.optimisetrial.eu/) is performed by a consortium of 20 institutions from 13 European countries, Israel and Australia. It is funded by the European Commission under the 7 th framework program. The study is coordinated by the University Medical Center (UMC) Utrecht. The trial consists of 8 work packages addressing important clinical questions in first episode schizophrenia. The work package that contains the medication algorithm addresses the following objectives:

1. To test the applicability of amisulpride as the first step in the treatment of first episode schizophrenia or schizophreniform disorder. 
Table 1. Summary of Prospective, Sequential Randomized Studies on Switching Antipsychotics

\begin{tabular}{|c|c|c|c|c|}
\hline $\begin{array}{l}\text { Author, } \\
\text { Country }\end{array}$ & Diagnosis & $\begin{array}{l}\text { "Run-in" phase: drugs } \\
\text { (dose), duration, blinding, } \\
\text { number of participants }\end{array}$ & $\begin{array}{l}\text { Randomized phase }{ }^{\mathrm{a}}: \text { drug } \\
\text { groups }(n) \text {, duration, blinding }\end{array}$ & Main result ${ }^{\mathrm{b}}$ \\
\hline $\begin{array}{l}\text { Kinon } \\
\text { et al, }{ }^{15} \text { USA }\end{array}$ & $\begin{array}{l}\text { Schizophrenia, } \\
\text { schizoaffective, or } \\
\text { schizophreniform } \\
\text { disorder DSM-III-R }\end{array}$ & $\begin{array}{l}\text { Fluphenazine } 20 \mathrm{mg} / \mathrm{d} \\
4 \mathrm{wk} \text {, open, } n=156\end{array}$ & $\begin{array}{l}\text { Switch to haloperidol } 20 \mathrm{mg} / \mathrm{d} \\
(n=13), \text { increase fluphenazine } \\
\text { dose to } 80 \mathrm{mg} / \mathrm{d}(n=16) \text { or stay on } \\
\text { fluphenazine } 20 \mathrm{mg} / \mathrm{d}(n=18), 4 \mathrm{wk}, \\
\text { db }\end{array}$ & $\begin{array}{l}\text { No significant efficacy difference } \\
\text { between groups. Only } 9 \% \\
\text { responded in the randomized } \\
\text { phase }\end{array}$ \\
\hline $\begin{array}{l}\text { Klimke } \\
\text { et al, } 19 \\
\text { Germany }\end{array}$ & $\begin{array}{l}\text { Acute } \\
\text { schizophrenia, } \\
\text { ICD-9 }\end{array}$ & $\begin{array}{l}\text { Haloperidol, } 15 \mathrm{mg} / \mathrm{d} \text {, } \\
3 \text { days, open, } n=50\end{array}$ & $\begin{array}{l}\text { Switch to perazine } 300 \mathrm{mg} / \mathrm{d}(n=12) \\
\text { or stay on haloperidol } 15 \mathrm{mg} / \mathrm{d} \\
(n=13), 3 \mathrm{wk}, \mathrm{db}\end{array}$ & $\begin{array}{l}\text { No significant difference between } \\
\text { groups }\end{array}$ \\
\hline $\begin{array}{l}\text { Shalev } \\
\text { et al, }{ }^{20} \text { Israel }\end{array}$ & $\begin{array}{l}\text { Schizophrenia, } \\
\text { chronic, or } \\
\text { subchronic with } \\
\text { acute exacerbation } \\
\text { DSM-III }\end{array}$ & $\begin{array}{l}\text { Haloperidol (target dose } \\
20 \mathrm{mg} / \mathrm{d} \text {, perphenazine } \\
\text { (target } 32 \mathrm{mg} / \mathrm{d} \text { ), } \\
\text { levomepromazine (target } \\
300 \mathrm{mg} / \mathrm{d} \text { ), open, } n=75\end{array}$ & $\begin{array}{l}\text { Second phase: Switch to one of the } \\
\text { remaining antipsychotics }(n=20) \text {, } \\
4 \mathrm{wk} \text {, open third phase: Switch to the } \\
\text { remaining drug }(n=9), 4 \mathrm{wk} \text {, open }\end{array}$ & $\begin{array}{l}\text { No significant difference between } \\
\text { groups. Overall improvement rate } \\
95 \%\end{array}$ \\
\hline $\begin{array}{l}\text { Suzuki } \\
\text { et al, }{ }^{21} \text { Japan }\end{array}$ & $\begin{array}{l}\text { Schizophrenia, } \\
\text { DSM-IV }\end{array}$ & $\begin{array}{l}\text { Olanzapine }{ }^{c} \text { flexible dose), } \\
\text { quetiapine (flexible dose) }{ }^{\mathrm{c}} \text {, } \\
\text { risperidone (flexible dose), } \\
\max .8 \mathrm{wk} \text {, open, } n=78\end{array}$ & $\begin{array}{l}\text { Second phase: Switch to one of the } \\
\text { remaining antipsychotics }(n=37) \text {, } \\
\text { max. } 8 \mathrm{wk} \text {, open. Third phase: } \\
\text { Switch to the remaining drug } \\
(n=19) \text {, max. } 8 \text { wk, open }\end{array}$ & $\begin{array}{l}\text { No significant differences between } \\
\text { drugs in the primary outcome. } \\
\text { Quetiapine less effective than } \\
\text { olanzapine and risperidone in } \\
\text { secondary outcomes }\end{array}$ \\
\hline $\begin{array}{l}\text { Hatta et al, },^{22} \\
\text { Japan }\end{array}$ & $\begin{array}{l}\text { Schizophrenia, } \\
\text { schizophreniform, } \\
\text { or schizoaffective } \\
\text { disorder, DSM-IV }\end{array}$ & $\begin{array}{l}\text { Risperidone (max. dose } \\
6 \mathrm{mg} / \mathrm{d}), 2 \mathrm{wk} \text {, open, } n=73\end{array}$ & $\begin{array}{l}\text { Olanzapine }(\max .20 \mathrm{mg} / \mathrm{d}) \text { or } \\
\text { risperidone }(\max .6 \mathrm{mg} / \mathrm{d}), n=20 \text {, } \\
2 \mathrm{wk}, \mathrm{sb}\end{array}$ & $\begin{array}{l}\text { No significant difference between } \\
\text { switchers and stayers. Early } \\
\text { responders improved more than } \\
\text { early nonresponders }\end{array}$ \\
\hline $\begin{array}{l}\text { Hatta et al, },^{22} \\
\text { Japan }\end{array}$ & $\begin{array}{l}\text { Schizophrenia, } \\
\text { schizophreniform, } \\
\text { or schizoaffective } \\
\text { disorder, DSM-IV }\end{array}$ & $\begin{array}{l}\text { Olanzapine (max. dose } \\
20 \mathrm{mg} / \mathrm{d}), 2 \mathrm{wk}, \mathrm{sb}, n=58\end{array}$ & $\begin{array}{l}\text { Risperidone }(\max .6 \mathrm{mg} / \mathrm{d}) \text {, } \\
\text { olanzapine }(\max .20 \mathrm{mg} / \mathrm{d}) \text { or, } n=20 \text {, } \\
2 \mathrm{wk}, \mathrm{sb}\end{array}$ & $\begin{array}{l}\text { No significant difference between } \\
\text { switchers and stayers. Early } \\
\text { responders improved more than } \\
\text { early nonresponders }\end{array}$ \\
\hline $\begin{array}{l}\text { Hatta et al, }{ }^{23} \\
\text { Japan }\end{array}$ & $\begin{array}{l}\text { Schizophrenia, } \\
\text { schizophreniform, } \\
\text { or schizoaffective } \\
\text { disorder, DSM-IV }\end{array}$ & $\begin{array}{l}\text { Risperidone (starting } \\
\text { dose } 3 \mathrm{mg} / \mathrm{d}, n=74 \text { ) or } \\
\text { olanzapine (starting dose } \\
10 \mathrm{mg} / \mathrm{d}, n=86 \text { ) chosen at } \\
\text { the physicians' discretion, } \\
2 \mathrm{wk}, \mathrm{sb}\end{array}$ & $\begin{array}{l}\text { Add the other drug or switch to the } \\
\text { respective other drug, same doses, } \\
10 \mathrm{wk}, n=51, \mathrm{sb}\end{array}$ & $\begin{array}{l}\text { No significant difference between } \\
\text { combining drugs and switching to } \\
\text { the other drug }\end{array}$ \\
\hline $\begin{array}{l}\text { McEvoy } \\
\text { et al, }{ }^{25} \text { USA }\end{array}$ & $\begin{array}{l}\text { Schizophrenia } \\
\text { DSM-IV }\end{array}$ & $\begin{array}{l}\text { Olanzapine }(7.5-30 \mathrm{mg} / \mathrm{d}) \text {, } \\
\text { perphenazine }(8-32 \mathrm{mg} / \mathrm{d}), \\
\text { quetiapine }(200-800 \mathrm{mg} / \mathrm{d}), \\
\text { risperidone }(1.5-6 \mathrm{mg} / \mathrm{d}), \\
\text { ziprasidone }(80-160 \mathrm{mg} / \mathrm{d}), \\
\text { max. } 18 \mathrm{mo}, \mathrm{db}, n=1493\end{array}$ & $\begin{array}{l}\text { Participants who discontinued phase } \\
1^{\mathrm{d}} \text { were randomized to clozapine, } \\
\text { olanzapine, quetiapine or risperidone } \\
\text { (patients could not receive the same } \\
\text { drug as in phase I), } n=99, \text { max. } 18 \\
\text { mo, db except clozapine }\end{array}$ & $\begin{array}{l}\text { Time to discontinuation was } \\
\text { significantly longer for clozapine } \\
\text { than for quetiapine and } \\
\text { risperidone, but not longer than } \\
\text { for olanzapine }\end{array}$ \\
\hline $\begin{array}{l}\text { Stroup } \\
\text { et al, }{ }^{26} \text { USA }\end{array}$ & $\begin{array}{l}\text { Schizophrenia } \\
\text { DSM-IV }\end{array}$ & $\begin{array}{l}\text { Olanzapine }(7.5-30 \mathrm{mg} / \mathrm{d}) \text {, } \\
\text { perphenazine }(8-32 \mathrm{mg} / \mathrm{d}) \text {, } \\
\text { quetiapine }(200-800 \mathrm{mg} / \mathrm{d}) \text {, } \\
\text { risperidone }(1.5-6 \mathrm{mg} / \mathrm{d}), \\
\text { ziprasidone }(80-160 \mathrm{mg} / \mathrm{d}) \text {, } \\
\max .18 \mathrm{mo}, \mathrm{db}, n=1493\end{array}$ & $\begin{array}{l}\text { Participants who discontinued } \\
\text { phase } \mathrm{I}^{\mathrm{d}} \text { were randomized to } \\
\text { ziprasidone, olanzapine, quetiapine, } \\
\text { or risperidone (patients could not } \\
\text { receive the same drug as in phase I), } \\
n=444, \max .18 \mathrm{mo}, \mathrm{db}\end{array}$ & $\begin{array}{l}\text { Time to discontinuation was } \\
\text { significantly longer for olanzapine } \\
\text { and risperidone than for } \\
\text { quetiapine and ziprasidone }\end{array}$ \\
\hline $\begin{array}{l}\text { Kinon } \\
\text { et } a 1,{ }^{30} \text { USA }\end{array}$ & $\begin{array}{l}\text { Schizophrenia, } \\
\text { schizophreniform, } \\
\text { or schizoaffective } \\
\text { disorder, DSM-IV }\end{array}$ & $\begin{array}{l}\text { Risperidone }(2-6 \mathrm{mg} / \mathrm{d}) \text {, } \\
2 \mathrm{wk} \text {, open, } n=628\end{array}$ & $\begin{array}{l}\text { Switch to olanzapine } 10-20 \mathrm{mg} / \mathrm{d} \\
\text { or staying on risperidone, } n=378 \text {, } \\
10 \mathrm{wk}, \mathrm{db}\end{array}$ & $\begin{array}{l}\text { Switchers to olanzapine had a } \\
\text { statistically significantly larger } \\
\text { symptom reduction than stayers } \\
\text { on risperidone. }\end{array}$ \\
\hline $\begin{array}{l}\text { Leucht et } \mathrm{al}^{31} \\
\text { ongoing } \\
\text { Germany, } \\
\text { Romania }\end{array}$ & $\begin{array}{l}\text { Schizophrenia or } \\
\text { schizoaffective } \\
\text { disorder DSM-IV }\end{array}$ & $\begin{array}{l}\text { Amisulpride ( } 200- \\
800 \mathrm{mg} / \mathrm{d}) \text { or olanzapine } \\
(5-20 \mathrm{mg} / \mathrm{d}), 2 \mathrm{wk} \\
\text { randomized, db, } n=350\end{array}$ & $\begin{array}{l}\text { Switching to the respective } \\
\text { other drug or staying on the same } \\
\text { drug, same doses, } 6 \mathrm{wk}, n=\text { not } \\
\text { indicated, db }\end{array}$ & Ongoing study \\
\hline
\end{tabular}

Note: DSM-IV, Diagnostic and Statistical Manual of Mental Disorders, Fourth Edition.

${ }^{a}$ We only describe the design for nonresponders in the run-in phase.

${ }^{\mathrm{b}}$ Significant means statistically significant, $n=$ number of participants, $\max .=$ maximum, $\mathrm{db}=\mathrm{double}-\mathrm{blind}$, $\mathrm{sb}=$ single-blind.

${ }^{c}$ Flexible doses within the licensed range.

The participants were not necessarily discontinued due to nonresponse in CATIE. 


\section{S. Leucht et al}

2. To test whether nonresponders to 4 weeks treatment with amisulpride benefit from a switch to an antipsychotic with a different receptor binding profile.

3. To examine the effectiveness of early use of clozapine in nonresponding first-episode patients. ${ }^{32}$

The following description focuses on methodological choices of this treatment trial which may be important for future trials. As mentioned above other work packages of OPTiMiSE (RCT on a psychosocial intervention, RCT on cannabidiol, imaging, extensive assessment of biological markers of response) will be described in companion articles.

\section{Study Flow}

Patients with a first episode of schizophrenia, schizophreniform, or schizoaffective disorder are treated for 4 weeks with open-label amisulpride in flexible doses $(200-800 \mathrm{mg} / \mathrm{d})$. Those patients who are not in remission (defined by the criteria of Andreasen et $\mathrm{al}^{9}$ ) at 4 weeks are randomized to 6 weeks double-blind treatment with either continuation of amisulpride (200-800 mg/d) or olanzapine $(5-20 \mathrm{mg} / \mathrm{d})$. Those who are still not in remission at the end of the RCT enter a 12-week open label trial with clozapine $(100-800 \mathrm{mg} / \mathrm{d})$. Those patients who achieve symptomatic remission ${ }^{9}$ at the end of any study phase and all patients who leave the clozapine phase are randomized to either treatment as usual or to the psychosocial intervention to improve adherence. A subgroup of participants and healthy controls undergo an expanded MRI protocol also consisting of Magnetic Resonance Spectroscopy (MRS) with 2 follow-up scans during the study. Blood tests for the biological predictors of response are taken at each study phase. All patients are followed up for 74 weeks (see figure 2 for an overview).

\section{Participants}

Five hundred patients with a first episode of schizophrenia, schizophreniform, or schizoaffective disorder according to Diagnostic and Statistical Manual of Mental Disorders, Fourth Edition (DSM-IV) verified with the Mini International Neuropsychiatric Interview Plus (M.I.N.I. Plus; Sheehan et $\mathrm{al}^{33}$ ) who have given written informed consent are included. The definition of first episode schizophrenia is based on the EUFEST study $^{34}$ and relatively strict compared to other trials of this kind ${ }^{35}$ : participants need to be aged between 18 and 40 years, have a maximum interval between the onset of psychosis and study entry of 2 years and have used antipsychotic medication no longer than an episode of 2 weeks in the previous year or 6 weeks lifetime. These

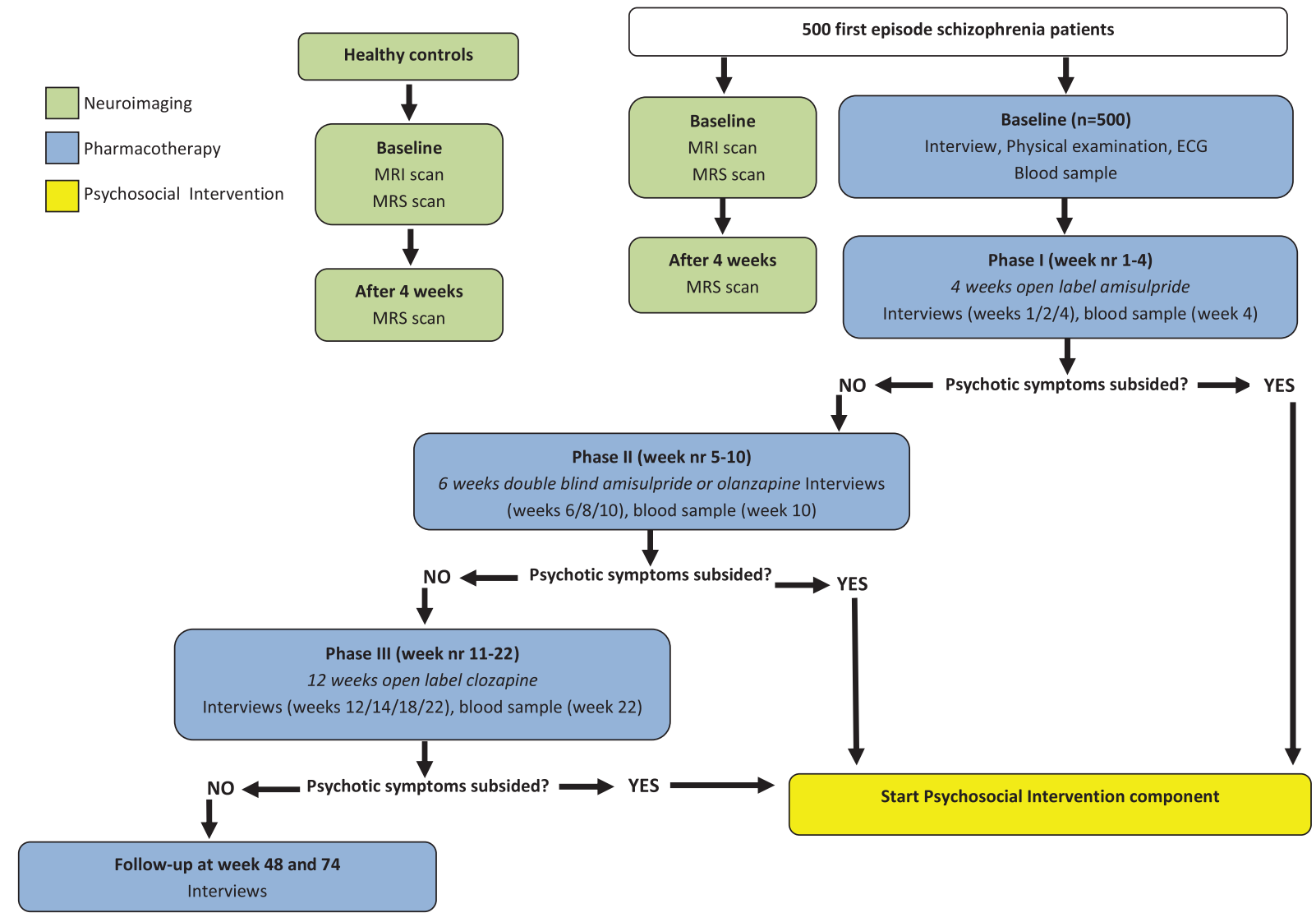

Fig. 2. Flowchart of the OPTiMiSE trial design. 
stringent criteria are important because we assume that true first-episode patients are likely to respond better to treatment than definitions of first episode patients for whom longer pretreatment is allowed.

\section{Rationale for Study Medication}

Phase I. The choice of amisulpride as the initial drug was based on the results of the European First Episode Schizophrenia Trial (EUFEST) ${ }^{34}$ in which amisulpride turned out as one of the most effective treatments, corroborated by several meta-analyses which suggested a high efficacy and low risk for metabolic and extrapyramidal side-effects. ${ }^{36-38}$ Amisulpride is also a unique "atypical" antipsychotic, because it is a selective D2/D3 (and 5-HT $7^{39}$ ) receptor antagonist with mesolimbic selectivity ${ }^{40}$ rather than a 5-HT2a receptor antagonist.

Phase II. To use olanzapine as the drug to which patients are randomly switched in phase II was again based on the EUFEST trial ${ }^{34}$ in which olanzapine together with amisulpride did best in the primary outcome "treatment discontinuation" due to any cause and the proportion of patients in remission applying the criteria defined by Andreasen et $\mathrm{al}^{9}$ Moreover, olanzapine is a multireceptor antagonist and its atypical properties are mainly explained by a stronger antagonism of central serotonin than of central dopamine receptors. ${ }^{41,42}$ It thus has a very different receptor binding profile than the selective D2/ D3 receptor antagonist amisulpride. This choice follows the hypothesis that nonresponders to one antipsychotic might respond to another one with a different receptor binding profile for which some evidence is available (see above $^{27,30}$ ).

Phase III. Clozapine is considered to be the most efficacious drug for treatment resistant schizophrenia and this has been shown in various individual RCTs ${ }^{43,44}$ and meta-analyses, ${ }^{37,38}$ one even in nonrefractory patients. ${ }^{36}$ Despite this evidence, there currently is on average a 48-month delay before eligible patients are prescribed clozapine in UK. ${ }^{45}$ As clozapine's efficacy stands out in meta-analyses of antipsychotic drugs, ${ }^{36,37}$ the notion that clozapine should be used earlier in treatment to avoid a chronic course has been put forward ${ }^{8}$ Case series $^{46}$ and $2 \mathrm{RCTs}^{32,47}$ have even examined clozapine as the first line treatment in first-episode patients, but the 2 RCTs ( 1 from China, ${ }^{47,48} 1$ from Spain ${ }^{32}$ ) have shown only a faster onset of action ${ }^{47}$ and/or a longer retention in treatment ${ }^{32,48}$ than comparator drugs. Given these results, the high response rates of first-episode patients in general and the tolerability issues around clozapine, a first-line application appears to be premature, but there is a case to consider clozapine as a second-line rather than third-line option. ${ }^{8}$ This argument has been based on a prospective study in which 244 first-episode patients were treated according to a stringent algorithm. ${ }^{49}$ They first received either olanzapine or risperidone for 4 weeks. Those who had not responded were switched to the respective other drug for another 4 weeks before they were - in case of nonresponse-switched to clozapine. About $75.4 \%$ of the patients responded to the first antipsychotic prescribed, with higher response to olanzapine than to risperidone. The response rate dropped to $16.7 \%$ for the second drug, but increased again to $75 \%$ when patients were switched to clozapine. The low response rate to the second drug and the big increase in response after switching to clozapine serve as a case to use clozapine as a second line treatment to avoid unnecessary loss of time. ${ }^{7}$ In this context, OPTiMiSE will be a systematic application of clozapine in nonresponding patients within the first 12 weeks of their treatment initiation, and the second antipsychotic for those participants who were randomized to continuation of amisulpride in phase II. Clozapine levels will be determined 3 times during this 12 weeks open label phase to guarantee optimum doses in a plasma-level target range of $400-1000 \mathrm{ng} / \mathrm{ml} .^{50}$

\section{Choice of Outcomes}

The primary outcome will be symptomatic remission according to the criteria of Andreasen et al ${ }^{9}: 8$ specific symptoms (PANSS items P1, P2, P3, N1, N4, N6, G5, and G9) of schizophrenia as measured by the Positive and Negative Syndrome Scale ${ }^{51}$ are at the most only mildly present (maximum rating of " 3 "). Compared to the frequently used response definitions based on cutoffs of percentage reduction of the PANSS total score for which no consensus exists $(20 \%, 30 \%, 40 \%, 50 \%$, $60 \%$ have all been used), remission is a "harder" outcome allowing for only a minimum of symptoms that does not interfere with daily life functioning. Good clinical validity has been demonstrated (for review see Lambert et al $^{52}$ ) and it has been shown to be a realistic goal of antipsychotic drug trials, ${ }^{53,54}$ including EUFEST. ${ }^{34}$ The use of these remission criteria will thus facilitate translating the study results into practice guidelines.

Secondary outcome measures are all-cause discontinuation, the Positive and Negative Syndrome Scale (PANSS) total score and subscores for which raters are trained, patients' overall severity and improvement of symptoms (CGI, ${ }^{16}$ levels of depression (Calgary Depression Scale for Schizophrenia, $\mathrm{CDSS}^{55}$ ), social functioning (Personal and Social Performance Scale, PSP ${ }^{56}$ Global Assessment of Functioning Scale, $\mathrm{GAF}^{57}$ ), and quality of life with the Subjective Wellbeing under Neuroleptics Scale $\left(\mathrm{SWN}^{58}\right)$. Tolerability is examined with the UKU side effects rating scale, ${ }^{59}$ we also measure weight gain, and assess further adverse events with open interviews.

\section{Statistical Analysis}

The primary outcome will be the number of patients in symptomatic remission according to Andreasen et al. ${ }^{8}$ 
The proportion of patients meeting remission criteria will be estimated at the end of phases I, II, and III. Logistic regression analyses will be used to test whether the probability of remission is significantly different between the amisulpride and olanzapine treatment arms at the end of phase II. Duration of untreated psychosis, age, and gender will be included as covariates in this analysis. The secondary outcome measure is all-cause treatment discontinuation, which will also be compared between treatment arms with survival analyses including Cox regression analyses and Kaplan-Meier functions.

\section{Study Progress and Outlook}

As of the date of submission of this manuscript, 372 participants have been included in phase I of the clinical trial, 79 have been randomized to phase II and 23 entered the clozapine phase. It is anticipated that the last patient will be included in November 2015, so that OPTiMiSE will finish in spring 2016. First results can be expected in summer 2016.

Prospective studies to examine treatment algorithms are difficult to carry out, because many patients respond to the first antipsychotic so that large sample sizes are needed for sufficient power in the subsequent phases. But given that only a handful of the 13542 controlled studies in the Cochrane register made such an attempt, most of them underpowered and none restricted to first episode patients, large studies to develop treatment algorithms are a priority to make treatment guidelines more meaningful.

\section{Funding}

European Commission within the 7th Program (HEALTH-F2-2010-242114).

\section{Acknowledgments}

We thank S. Longhi for her help in the selection of studies. S. Leucht has received lecture honoraria from EliLilly, Lundbeck, Pfizer, Janssen, Johnson and Johnson, BristolMyersSquibb, Lundbeck, Roche, SanofiAventis, ICON and Abbvie; honoraria for consulting from Roche, Janssen, Lundbeck, and EliLilly; for the preparation of educational material and publications from the Lundbeck Institute and Roche. EliLilly has provided medication for a clinical trial led by SL as principal investigator. Eli Lilly has provided medication for a study with SL as primary investigator. I. Winter has no conflicts to declare. S. Heres has received honoraria from Janssen-Cilag, Eli Lilly, Sanofi-Aventis, Lundbeck, and Johnson \& Johnson, he has accepted travel or hospitality payment from JanssenCilag, Sanofi-Aventis, Johnson \& Johnson, Pfizer, BristolMyers-Squibb, AstraZeneca, Lundbeck, Novartis, and Eli Lilly, he has participated in clinical trials sponsored or supported by Eli Lilly, Janssen Cilag, Johnson \& Johnson,
Bristol-Myers-Squibb, AstraZeneca, Otsuka, Lundbeck, Novartis, Servier, Pierre Fabre, Pfizer, Organon, Roche, and Merck, and he has participated in advisory activities and boards for Janssen, Johnson \& Johnson, Eli Lilly, Lundbeck, Otsuka, and Roche. C. Arango has been a consultant to or has received honoraria or grants from Abbot, AMGEN, AstraZeneca, Bristol-Myers Squibb, Caja Navarra, CIBERSAM, Fundación Alicia Koplowitz, Instituto de Salud Carlos III, Janssen Cilag, Lundbeck, Merck, Ministerio de Ciencia e Innovación, Ministerio de Sanidad, Ministerio de Economía y Competitividad, Mutua Madrileña, Otsuka, Pfizer, Roche, Servier, Shire, Takeda, and Schering Plough. W. W. Fleischhacker has received grants from Otsuka, Janssen, Lundbeck; and honoraria for advisory boards and speaker activities from Janssen, Lundbeck, Otsuka, Teva, Roche, AOP Orphan, Dainippon Sumitomo. Birte Glenthøj is the leader of a Lundbeck Foundation Center of Excellence for Clinical Intervention and Neuropsychiatric Schizophrenia Research (CINS) which is partially financed by an independent grant from the Lundbeck Foundation based on international review and partially financed by the Mental Health Services in the Capital Region of Denmark, the University of Copenhagen, and other foundations. She has nothing else to declare. Shôn Lewis has received lecture fees from Janssen and Abbvie and research contributions from Lilly, Janssen, Astrazeneca, Pfizer, and Novartis. D. Rujescu has received honoraria for consulting/advisory boards from Roche, Janssen, and Takeda. R. S. Kahn is member of Data Monitoring Committees for Janssen, Otsuka, Roche, and Sunovion. I. Sommer has no conflicts of interest to declare.

\section{References}

1. Vos T, Flaxman AD, Naghavi M, et al. Years lived with disability (YLDs) for 1160 sequelae of 289 diseases and injuries 1990-2010: a systematic analysis for the Global Burden of Disease Study 2010. Lancet 2012;380:2163-2196.

2. Fraguas D, Merchán-Naranjo J, del Rey-Mejías Á, et al. A longitudinal study on the relationship between duration of untreated psychosis and executive function in early-onset first-episode psychosis. Schizophr Res. 2014;158:126-133.

3. Diaz I, Pelayo-Teran JM, Perez-Iglesias R, et al. Predictors of clinical remission following a first episode of non-affective psychosis: sociodemographics, premorbid and clinical variables. Psychiatry Res. 2013;206:181-187.

4. Faber G, Smid HG, Van Gool AR, Wiersma D, Van Den Bosch RJ. The effects of guided discontinuation of antipsychotics on neurocognition in first onset psychosis. Eur Psychiatry. 2012;27:275-280.

5. Jordan G, Lutgens D, Joober R, Lepage M, Iyer SN, Malla A. The relative contribution of cognition and symptomatic remission to functional outcome following treatment of a first episode of psychosis. J Clin Psychiatry. 2014;75:e566-e572.

6. Lieberman JA, Koreen AR, Chakos M, et al. Factors influencing treatment response and outcome of first-episode schizophrenia: implications for understanding the pathophysiology of schizophrenia. J Clin Psychiatry. 1996;57(suppl 9):5-9. 
7. Emsley R, Oosthuizen P, Koen L, Niehaus D, Martinez L. Comparison of treatment response in second-episode versus first-episode schizophrenia. J Clin Psychopharmacol. 2013;33:80-83.

8. Remington G, Agid O, Foussias G, Hahn M, Rao N, Sinyor M. Clozapine's role in the treatment of first-episode schizophrenia. Am J Psychiatry. 2013;170:146-151.

9. Andreasen N, Carpenter W, Kane J, Lasser R, Marder $\mathrm{S}$, Weinberger D. Remission in schizophrenia: proposed criteria and rationale for consensus. Am J Psychiatry 2005;62:441-449.

10. Kane JM, Honigfeld G, Singer J, Meltzer H, group atCCs. Clozapine for the treatment-resistant schizophrenic. A double-blind comparison with chlorpromazine. Arch Gen Psychiatry. 1988;45:789-796.

11. Kane JM, Meltzer HY, Carson WH, McQuade RD, Marcus RN, Sanchez R. Aripiprazole for treatment-resistant schizophrenia: Results of a multicenter, randomized, double-blind, comparison study versus perphenazine. J Clin Psychiatry. 2007;68:213-223.

12. Kane JM, Khanna S, Rajadhyaksha S, Giller E. Efficacy and tolerability of ziprasidone in patients with treatment-resistant schizophrenia. Int Clin Psychopharmacol. 2006;21:21-28.

13. Emsley RA, Raniwalla J, Bailey PJ, Jones AM. A comparison of the effects of quetiapine ('Seroquel') and haloperidol in schizophrenic patients with a history of and a demonstrated, partial response to conventional antipsychotic treatment. Int Clin Psychopharmacol. 2000;15:121-131.

14. Conley RR, Tamminga CA, Bartko JJ, et al. Olanzapine compared with chlorpromazine in treatment-resistant schizophrenia. Am J Psychiatry. 1998;155:914-920.

15. Kinon BJ, Kane JM, Johns C, Perovich R, Ismi M, Koreen A, Weiden P. Treatment of neuroleptic-resistant schizophrenic relapse. Psychopharmacol Bull. 1993;29:309-314.

16. Guy W. Clinical global impression. ECDEU assessment manual for psychopharmacology, revised (DHEW Publ No ADM 76-338). National Institute of Mental Health; 1976:218-222.

17. Overall JE, Gorham DR. The brief psychiatric rating Scale. Psychol Rep 1962;10:790-812.

18. Gardner DM, Murphy AL, O'Donnell H, Centorrino F, Baldessarini RJ. International consensus study of antipsychotic dosing. Am J Psychiatry. 2010;167:686-693.

19. Klimke A, Klieser E, Lehmann E, Miele L. Initial improvement as a criterion for drug choice in acute schizophrenia. Pharmacopsychiatry. 1993;26:25-29.

20. Shalev A, Hermesh H, Rothberg J, Munitz H. Poor neuroleptic response in acutely exacerbated schizophrenic patients. Acta Psychiatr Scand. 1993;87:86-91.

21. Suzuki T, Uchida H, Watanabe K, et al. How effective is it to sequentially switch among Olanzapine, Quetiapine and Risperidone?-A randomized, open-label study of algorithm-based antipsychotic treatment to patients with symptomatic schizophrenia in the real-world clinical setting. Psychopharmacology. 2007;195:285-295.

22. Hatta K, Otachi T, Sudo Y, et al. Difference in early prediction of antipsychotic non-response between risperidone and olanzapine in the treatment of acute-phase schizophrenia. Schizophr Res. 2011;128:127-135.

23. Hatta K, Otachi T, Fujita K, et al. Antipsychotic switching versus augmentation among early non-responders to risperidone or olanzapine in acute-phase schizophrenia. Schizophr Res. 2014;158:213-222.
24. Lieberman JA, Stroup TS, McEvoy JP, et al. Effectiveness of antipsychotic drugs in patients with chronic schizophrenia. $N$ Engl J Med. 2005;353:1209-1223.

25. McEvoy JP, Lieberman JA, Stroup TS, et al. Effectiveness of clozapine versus olanzapine, quetiapine, and risperidone in patients with chronic schizophrenia who did not respond to prior atypical antipsychotic treatment. Am J Psychiatry. 2006;163:600-610.

26. Stroup TS, Lieberman JA, McEvoy JP, et al. Effectiveness of olanzapine, quetiapine, risperidone, and ziprasidone in patients with chronic schizophrenia following discontinuation of a previous atypical antipsychotic. Am J Psychiatry. 2006;163:611-622.

27. Stroup TS, Lieberman JA, McEvoy JP, et al. Effectiveness of olanzapine, quetiapine, and risperidone in patients with chronic schizophrenia after discontinuing perphenazine: A CATIE study. Am J Psychiatry. 2007;164:415-427.

28. Essock SM, Covell NH, Davis SM, Stroup TS, Rosenheck RA, Lieberman JA. Effectiveness of switching antipsychotic medications. Am J Psychiatry. 2006;163:2090-2095.

29. Rosenheck RA, Davis S, Covell N, et al. Does switching to a new antipsychotic improve outcomes? Data from the CATIE Trial. Schizophr Res. 2009;107:22-29.

30. Kinon BJ, Chen L, scher-Svanum H, et al. Early response to antipsychotic drug therapy as a clinical marker of subsequent response in the treatment of schizophrenia. Neuropsychopharmacology. 2010;35:581-590.

31. Leucht S, Heres S. The Switch Study - efficacy of an early antipsychotic switch in case of poor initial response to the treatment of schizophrenia (NCT01029769). Clinicaltrialsgov. 2009.

32. Sanz-Fuentenebro J, Taboada D, Palomo T, et al. Randomized trial of clozapine vs. risperidone in treatment-naive firstepisode schizophrenia: results after one year. Schizophr Res. 2013;149:156-161.

33. Sheehan DV, Lecrubier Y, Sheehan KH, et al. The MiniInternational Neuropsychiatric Interview (M.I.N.I.): the development and validation of a structured diagnostic psychiatric interview for DSM-IV and ICD-10. J Clin Psychiatry. 1998;59(suppl 20):22-33.

34. Kahn RS, Fleischhacker WW, Boter H, et al. Effectiveness of antipsychotic drugs in first-episode schizophrenia and schizophreniform disorder: an open randomised clinical trial. Lancet 2008;371:1085-1097.

35. Lieberman JA, Tollefson G, Tohen M, et al. Comparative efficacy and safety of atypical and conventional antipsychotic drugs in first-episode psychosis: A randomized, double-blind trial of olanzapine versus haloperidol. Am J Psychiatry. 2003;160:1396-1404.

36. Leucht S, Cipriani A, Spineli L, et al. Comparative efficacy and tolerability of 15 antipsychotic drugs in schizophrenia: a multiple-treatments meta-analysis. Lancet. 2013;382:951-962.

37. Davis JM, Chen N, Glick ID. A meta-analysis of the efficacy of second-generation antipsychotics. Arch Gen Psychiatry. 2003;60:553-564.

38. Geddes J, Freemantle N, Harrison P, Bebbington P. Atypical antipsychotics in the treatment of schizophrenia: systematic overview and meta-regression analysis. $B M J$ 2000;321:1371-1376.

39. Abbas AI, Hedlund PB, Huang XP, Tran TB, Meltzer HY, Roth BL. Amisulpride is a potent 5-HT7 antagonist: relevance for antidepressant actions in vivo. Psychopharmacology. 2009;205:119-128. 
40. Schoemaker H, Claustre Y, Fage D, et al. Neurochemical characteristics of amisulpride, an atypical dopamine D2/D3 receptor antagonist with both presynaptic and limbic selectivity. J Pharmacol Exp Therapy 1997;280:83-97.

41. Perrault G, Depoortère R, Morel E, Sanger DJ, Scatton B. Psychopharmacological profile of amisulpride: an antipsychotic drug with presynaptic D2/D3 dopamine receptor antagonist activity and limbic selectivity. $J$ Pharmacol Experiment Res. 2000;280:73-82.

42. Bymaster F, Perry KW, Nelson DL, et al. Olanzapine: a basic science update. Br J Psychiatry. 1999;174(suppl 37):36-40.

43. Kane JM, Honigfeld G, Singer J, Meltzer H, group. atCCs. Clozapine for the treatment-resistant schizophrenic. A double-blind comparison with chlorpromazine. Arch Gen Psychiatry. 1988;45:789-796.

44. Lewis SW, Barnes TR, Davies L, et al. Randomized controlled trial of effect of prescription of clozapine versus other second-generation antipsychotic drugs in resistant schizophrenia. Schizophr Bull. 2006;32:715-723.

45. Howes OD, Vergunst F, Gee S, McGuire P, Kapur S, Taylor D. Adherence to treatment guidelines in clinical practice: study of antipsychotic treatment prior to clozapine initiation. Br J Psychiatry. 2012;201:481-485.

46. Woerner MG, Robinson DG, Alvir JM, Sheitman BB, Lieberman JA, Kane JM. Clozapine as a first treatment for schizophrenia. Am J Psychiatry. 2003;160:1514-1516.

47. Lieberman JA, Phillips M, Gu H, et al. Atypical and conventional antipsychotic drugs in treatment-naive firstepisode schizophrenia: a 52-week randomized trial of clozapine vs chlorpromazine. Neuropsychopharmacology. 2003;28:995-1003.

48. Girgis RR, Phillips MR, Li X, et al. Clozapine v. chlorpromazine in treatment-naive, first-episode schizophrenia: 9-year outcomes of a randomised clinical trial. $\mathrm{Br} J$ Psychiatry. 2011;199:281-288.

49. Agid O, Arenovich T, Sajeev G, Zipursky RB, Kapur S, Foussias G, Remington G. An algorithm-based approach to first-episode schizophrenia: response rates over 3 prospective antipsychotic trials with a retrospective data analysis. $J$ Clin Psychiatry. 2011;72:1439-1444.

50. Schulte P. What is an adequate trial with clozapine?: therapeutic drug monitoring and time to response in treatment-refractory schizophrenia. Clin Pharmacokinet. 2003;42:607-618.

51. Kay SR, Fiszbein A, Opler LA. The positive and negative syndrome scale (PANSS) for schizophrenia. Schizophr Bull. 1987;13:261-276.

52. Lambert M, Karow A, Leucht S, Schimmelmann BG, Naber D. Remission in schizophrenia: validity, frequency, predictors, and patients' perspective 5 years later. Dialogues Clin Neurosci. 2010;12:393-407.

53. Beitinger R, Lin J, Kissling W, Leucht S. Comparative remission rates of schizophrenic patients using various remission criteria. Prog Neuropsychopharmacol Biol Psychiatry. 2008;32:1643-1651.

54. Leucht S, Beitinger R, Kissling W. On the concept of remission in schizophrenia. Psychopharmacology. 2007;194:453-461.

55. Addington D, Addington J, Schissel B. A depression rating scale for schizophrenics. Schizophr Res. 1990;3:247-251.

56. Morosini PL, Magliano L, Brambilla L, Ugolini S, Pioli R. Development, reliability and acceptability of a new version of the DSM-IV Social and Occupational Functioning Assessment Scale (SOFAS) to assess routine social functioning. Acta Psychiatr Scand. 2000;101:323-329.

57. Jones SH, Thornicroft G, Coffey M, Dunn G. A brief mental health outcome scale-reliability and validity of the Global Assessment of Functioning (GAF). Br J Psychiatry. 1995; 166:654-659.

58. Naber D. A self-rating to measure subjective effects of neuroleptic drugs, relationships to objective psychopathology, quality of life, compliance and other clinical variables. Int Clin Psychopharmacol. 1995;10(suppl 3):133-138.

59. Lingjaerde O, Ahlfors UG, Bech P, Dencker SJ, Elgen K. The UKU side effect rating scale. A new comprehensive rating scale for psychotropic drugs and a cross-sectional study of side effects in neuroleptic-treated patients. Acta Psychiatr Scand Suppl. 1987;334:1-100. 